\title{
Differences in physical activities and food-related practices in relation to perceived parenting styles among (pre-) adolescents aged from 10 to 15
}

\begin{abstract}
The main objective of the study is to identify the differences in risk behaviour in terms of physical activities and food-related practices in relation to parenting styles as perceived by (pre-) adolescents. The Eating Habits and Activities subscale of the Questionnaire of Risk Behaviour (QRB), consisting of seven items, was used to examine specific forms of risk behaviour, while a standardized questionnaire for detecting parenting styles in the family (DZSVR) was used to examine parenting styles: democratic, authoritarian, liberal, and indifferent. The research sample consists of (pre-) adolescents in elementary schools in all regions of the Slovak Republic, specifically 606 (pre-) adolescents aged between 10 and 15 years old. The results show that the lowest mean scores for all forms of risk behaviours are shown by (pre-) adolescents who have been raised with democratic and authoritarian parenting styles; (pre-)adolescents who have been raised with liberal and indifferent parenting styles show higher mean scores on the assessed variables. However, statistically significant differences were found only in soft drink consumption $(H=8.615, p<.05)$, the frequency of eating breakfast $(H=11.944, p<.001)$, and the time spent watching TV $(H=7.658, p<.05)$.
\end{abstract}

Keywords: risk behaviour, parenting styles, adolescence, eating habits, physical activity

\section{Introduction}

Parents are important influences on children's behaviour, and this influence is likely to be a function of parenting styles and practices. Research suggests that each style is followed by particular effects, results, and consequences. Some styles (educational practices) lead to children's risk behaviour. According to Gray and Jennings (1999), risk behaviour is a tendency to behave in a way that has the potential to be harmful or dangerous, and at the same time provides an opportunity for a result that is rated positively by the individual or is somewhat beneficial for him/her. In the context of the summary of the views of several authors (Arnett, 2000; Čerešník, 2016; Čerešník \& Čerešníková, 2019; Jessor, 1991; Labáth, 2001; Newman, Harrison, Dashiff, \& Davies, 2008) risk behaviour includes: addictive behaviour, risky sexual behaviour, aggressive behaviour, violence and unintentional injuries, delinquency, crime, bullying, school failure/ leaving school/negative attitude towards school, inappropriate eating habits, and lack of physical activity and inactivity. Even though the literature and research often deal with more serious forms of risk behaviours (e.g. addictive and sexual risk behaviour, delinquency, etc.), forms of risk behaviours such as a lack of physical activity or unhealthy eating habits can also cause health issues. These forms of risk behaviours are highly influenced by parents. For example, feeding practices refer to the specific goal-directed behaviours used by parents to directly influence their children's eating. This might include attempts to increase or reduce their intake of certain foods. Common feeding practices include: modelling eating behaviours, restricting certain types of food, pressuring children to eat, rewarding positive behaviours with food, and the availability of food at home (Shloim, 2015). However, many children do not meet the guidelines for food-related practices or physical activity (Troiano, 2008). The objective of the study is to identify the differences in risk behaviour in terms of physical activity and spending leisure time (exercise, watching TV, and using a PC) and food-related practices (consumption of vegetables, fruits, and soft drinks) in relation to the parenting styles as perceived by the children.

\section{Theoretical and empirical background}

The development of personality and its improvement during life is the result of various influences and education, and is also conditioned by inherited attributes. The process of shaping personality starts before the birth of a child, but it is most intense in the period of preadolescence and adolescence. The improvement and development of personality continue throughout life, but this progress is considerably smaller compared to childhood and adolescence. There are numerous factors that determine the development of personality and have an influence on this process, but the most significant are hereditary, society, and the family environment, also mentioned as internal and external determinants. The material and social environment of the individual has a greater influence on the formation of personality. The material environment means the quality of the environment (climatic conditions, natural environment, environmental changes, etc.), while the social environment is the environment in which a person grows (most often their family and school; Strejček, 2009). According to Šnýdrová (2008), the family is the most important factor which influences the formation and maturation of the personality. Parenting styles describe how a parent communicates with his/her child. Four parenting styles 
have been defined: authoritarian (demanding obedience), authoritative (democratic; using reasoning), permissive (acquiescing to the child $>$ s demands), and uninvolved. Parenting practices describe context-specific behaviours such as what a parent does to facilitate food-related practices and physical activity (Gustafson \& Rhodes, 2006; Pugliese \& Tinsley, 2007; Jago, 2017). Kausar \& Pinquart (2016) focus their attention on summarizing the empirical findings that point to the relationship between parenting styles and risk behaviours:

- an authoritative (democratic) parenting style that is linked to a high level of demands on (pre-) adolescents and an emotionally positive relationship minimizes the likelihood of risk behaviour; it provides a balance between constraint and autonomy and promotes the self-confidence of (pre-) adolescents and provides a basis for the psychosocial maturity of (pre-) adolescents;

- the authoritarian parenting style is associated with high demands on the child and low emotional contributions to the parent-child relationship, and correlates highly with risk behaviour;

- a permissive (liberal) parenting style is characterized by a low level of requirements and a positive emotional relationship associated with high sensitivity; it is also associated with an increased level of risk behaviour; children of liberal parents are more affected by risky peers;

- neglectful parents are neither demanding nor responsive. They have no specific rules, lack warmth, support, and intimacy, and have no supervision and control over their children's behaviours; uninvolved parenting correlates highly with children's risk behaviour. Similarly, an indifferent parenting style is also considered to be problematic; it is characterized by the discrepancy in the requirements placed on a child (Čáp \& Boschek, 1994); this approach creates neuroticism and confusion and leads to risk behaviour (e.g. delinquency, bullying, a negative attitude towards school, or addictive behaviour).

Some research studies have found direct associations between parenting styles (or parenting practices) and the forms of risk behaviour of children, which we also analyze in the present study.

- As the literature suggests, more controlling and restrictive parents have children with lower physical activity levels (Prezza, Pilloni, Morabito, \& Sersante, 2001). The varying domains of parental influence may have lasting effects on their children's physical activity, with numerous studies reflecting the importance of parental involvement and encourage- ment specifically (Brustad, 1993; Chiarlitti \& Kolen, 2017).

- Results indicated that authoritative feeding was positively associated with the availability of fruits and vegetables and attempts to get the child to eat those foods. In contrast, authoritarian feeding was associated with lower availability of fruits and vegetables. In addition, the actual consumption of these foods varied according to the feeding style; authoritative feeding was positively associated with the consumption of dairy and vegetables, whereas authoritarian feeding was negatively associated with vegetable intake (Savage, Fisher, \& Birch, 2007).

- Interventions aiming to reduce children's screen time should be family-based, start during early childhood, and target modifiable factors in the home setting (Darling \& Steinberg, 1993; Abar, Carter, \& Winsler, 2009). Previous studies found that family rules on watching TV are associated with less TV viewing (Barradas, Fulton, Blanck, \& Huhman, 2007; Salmon, Timperio, Telford, Carver, \& Crawford, 2005) and that high child autonomy is associated with more TV viewing (Anuthawar, 2008; Veldhui, Grieken, Renders, HiraSing, \& Raat, 2012).

- Abedini, Zamani, Kheradmand, \& Rajabizadeh (2012) found a significant correlation between addiction to computer games and parenting styles (democratic, authoritarian, liberal, neglectful); however, the level of correlation varied. The strongest correlation was found between addiction to computer games and authoritarian $\left(\mathrm{r}=.51^{\star *}\right)$ and neglectful parenting styles $\left(\mathrm{r}=.40^{\star *}\right)$, while the correlation with democratic $\left(\mathrm{r}=.24^{* *}\right)$ or liberal styles $\left(\mathrm{r}=.32^{* *}\right)$ was lower. However, parenting styles were limited only to the mother's approach.

On the basis of the previous studies mentioned above, we formulate the following predictions (hypotheses) on the differences between the levels of risk behaviour related to physical activity and the food-related practices of individuals raised with different parenting styles: (A) we assume that individuals raised with a democratic (authoritative) parenting style will exhibit a low level of risk behaviour (all forms examined); (B) we assume that individuals raised with a liberal (permissive) or indifferent parenting style will exhibit a high level of risk behaviour (all forms examined); (C) we assume that individuals raised with an authoritarian parenting style will exhibit different levels of risk behaviour: specifically, frequent consumption of soft drinks, low consumption of fruits and vegetables, lack of physical activity and exercise, and frequent TV watching and PC use (low autonomy). 


\section{Methods}

The aim of this research study is to point out the importance of parenting styles in relation to specific forms of risk behaviour in (pre-) adolescents. This aim involves measuring the difference in the level of specific forms of risk behaviour with respect to the perceived parenting style as judged by (pre-) adolescents. In order to confirm the predictions mentioned above, it was decided to carry out quantitatively-oriented research. Standardized and validated research tools were chosen (questionnaires, paper form) for measuring the research variables. The whole research tool consists of two full questionnaires for the measurement of the research variables and one questionnaire for the detection of the demographic information of the participants. The participants submitted questionnaires with their parents' consent to the processing of their data. All the questionnaires were anonymous. The data was collected by psychologists at Slovak universities. The participants had 90 minutes to complete the questionnaires. The complete version of the research tool was elaborated and piloted in February 2018. The data was collected in March-June 2018 and processed and analyzed in December 2018.

\subsection{Instruments}

Standardized and validated research tools were chosen for the study: the standardized questionnaire DZSVR (Questionnaire for detecting parenting styles in the family, originally in Slovak: Dotazník na zistovanie štýlov výchovy v rodine, hereinafter DZSVR) for detecting parenting styles and for the measurement of physical activity and food-related practices, we chose the QRB Questionnaire (Questionnaire of Risk Behaviour, originally in Slovak: Dotazník rizikového správania).

The authors of the DZSVR questionnaire are Čáp and Boschek (1994). In this questionnaire, (pre-) adolescents characterize the behaviour of their parents in the most common situations. From the beginning of the 'seventies, the questionnaire was gradually modified on the basis of the results of various research studies. In its current form, the questionnaire consists of 40 items, ten for each of the four parenting components. The questionnaire contains a requirements and freedom that corresponds to parental attitudes (based on Schludermann's and Schaefer's CRPBI questionnaire): positive, hostile, directive, and autonomous. The items are administered separately for the mother and father and the answers are recorded on a three-point scale (yes, partially, no). By combining the individual components, it is possible to identify four parenting styles: integrative (democratic), indifferent, liberal, and authoritarian (Čáp \& Boschek, 1994; Mayerová, 2013). The Cronbach $>$ alpha of the subclasses ranges from $\alpha=.69$ to $\alpha=.82$ (Tomšik \& Čerešník, 2017).
The Questionnaire of Risk Behaviour (QRB) is a method developed by Čerešník (2016). It consists of 38 items which are derived from the clinical indicators of risk behaviour. They are divided into six subscales: (1) family relations and rituals, (2) school and friendship, (3) addictive behaviour, (4) delinquent behaviour, (5) bullying, (6) eating habits and activities. There is also the possibility of calculating the total score for the risk behaviour. Participants evaluate the items through a Likert scale with various possible answers. For the purposes of this study, we use the Eating Habits and Activities subscale, which consists of the following seven items $(\alpha=.68)$ :

- How many times a week do you have breakfast?

- How many times a week do you consume raw vegetables?

- How many times a week do you consume fruit?

- How many times a week do you drink soft drinks?

- How many times a week do you train or exercise for more than an hour (outside school)?

- How many hours a day do you watch TV?

- How many hours a day do you spend using a computer?

\subsection{Research sample}

The research data was acquired from 606 (pre-) adolescents in lower secondary education in Slovakia, 250 boys and 350 girls in the age range from 10 to 15 (six of them did not supply data about their sex). Their average age was 12.75 years, with a standard deviation 1.483. The reference population was 203,172 (pre-) adolescents attending the fifth to ninth grades of state elementary schools in the 2017/2018 school year (ÚIAP, 2018). We collected the data in all the regions of Slovakia. The representation of the grades was approximately equivalent. The research sample was divided into four subgroups based on perceived parenting styles: democratic (11\%), indifferent (57\%), liberal (20\%), and authoritarian (12\%).

\subsection{Statistical analysis}

The statistical analyses were conducted in the following order: testing the normality of data distribution using a Kolmogorov-Smirnov KS test with Lilliefors correction and with Skewness and Kurtosis, internal consistencies of each subscale, descriptive statistics, and comparison analysis. The Skewness and Kurtosis of the majority of variables were given within -1.5 to 1.5 and the Kolmogorov-Smirnov test indicates that the variables do not fulfil the criteria of normality (in all variables $\mathrm{p}<.001)$. On the basis of these results, nonparametric tests were chosen for further statistical analyses, specifically the Kruskal-Wallis $\mathrm{H}$ test. To create graphs, the data was transformed into a Z-score. All the analyses were performed using SPSS v.21.0. 


\section{Results}

The largest number of respondents out of the total number of respondents $(\mathrm{N}=606), 57 \%$, were raised with an indifferent parenting style $(\mathrm{n}=347)$. In total, $20 \%$ $(\mathrm{n}=121)$ of the respondents were raised with a liberal parenting style and $12 \%(\mathrm{n}=70)$ with an authoritarian parenting style, while $11 \%(n=68)$ of the respondents were raised with a democratic parenting style. Compared to the norms, determined by Čáp and Boschek (1994), the distribution of individuals according to the parenting style was similar to the distribution in our research sample (category up to 17 years old). However, in our research sample we detected a higher number of (pre-) adolescents who had been raised with an indifferent parenting style (norm 44\%) and a lack of (pre-) adolescents who had been raised with a democratic parenting style (norm $24.0 \%$ ).

Table 1 presents the descriptive statistics of the individual items on the Eating Habits and Activities subscale. Variable scores may range from 1 to 3, with a higher score reflecting higher risk behaviour. Observing arithmetic means, the (pre-) adolescents scored low on spending time on using a computer, watching television, and eating fruit. Somewhat higher scores were observed for the number of breakfasts and amount of exercise, while the highest average scores were been observed for the consumption of soft drinks and vegetables. However, the scores for the individual variables are not high, given the possible variance of the scale.

Table 1: Physical activities and food-related practices among 10-15-year-old (pre-) adolescents (descriptive statistics)

\begin{tabular}{|c|c|c|c|c|c|c|}
\hline Variables & $\mathrm{N}$ & M & SEM & SD & SK & KU \\
\hline How many times a week do you have breakfast? & 606 & 1.107 & .038 & 1.206 & .424 & -1.460 \\
\hline How many times a week do you consume raw vegetables? & 606 & 1.591 & .034 & 1.090 & -.136 & -1.274 \\
\hline How many times a week do you consume fruit? & 606 & .928 & .030 & .953 & .630 & -.716 \\
\hline How many times a week do you drink soft drinks? & 606 & 1.309 & .035 & 1.114 & .328 & -1.242 \\
\hline $\begin{array}{l}\text { How many times a week do you train or exercise } \\
\text { for more than an hour (outside school)? }\end{array}$ & 606 & 1.241 & .034 & 1.073 & .358 & -1.133 \\
\hline How many hours a day do you watch TV? & 606 & .806 & .027 & .862 & .981 & .381 \\
\hline How many hours a day do you spend using a computer? & 606 & .700 & .030 & .948 & 1.234 & .455 \\
\hline
\end{tabular}

Note: $\mathrm{N}=$ number, $\mathrm{M}=$ mean, $\mathrm{SEM}=$ standard error of mean, $\mathrm{SD}=$ standard deviation, $\mathrm{SK}=$ skewness, $\mathrm{KU}=$ kurtosis

When assessing differences in risk behaviour (specifically, eating habits and activities), different results were found. Statistically significant differences were found in the variables: How many times a week do you have breakfast? $\left(\mathrm{H}=11.944^{\star * *}\right)$, How many times a week do you drink soft drinks? $\left(\mathrm{H}=8.615^{\star}\right)$, and How many hours a day do you watch TV? $\left(\mathrm{H}=7.658^{\star}\right)$. Generally, the lowest level of risk behaviour appears in the group of individuals who had been raised with a democratic parenting style. These individuals received the lowest average score for all the variables considered, meaning that (given that the scales are oriented to express the degree of risk) they eat breakfast more frequently, consume vegetables and fruit more frequently, exercise more often, consume soft drinks the least, and spend the least time using a computer and watching TV. The individuals who had been raised with an authoritarian parenting style scored similarly to individuals who had been raised with a democratic parenting style in terms of their frequency of exercise and TV and PC usage. However, they are the highest-risk group in terms of their consumption of fruit and vegetables (the lowest level of consumption). On the basis of the average score, individuals who had been raised with a liberal parenting style were shown to be the highest-risk group in terms of eating habits and activity. They scored high on all the variables except fruit consumption. Similar scores were achieved by the individuals who had been raised with an indifferent parenting style. Nevertheless, we found a mean difference in the variables: How many times a week do you consume raw vegetables?, How many times a week do you consume fruits?, How many times a week do you train or exercise for more than an hour (outside school)?, and How many hours a day do you spend using a computer?, but the difference is not statistically significant (see Table 2, Graph 1). 
Table 2: Differences in physical activity and food-related practices in relation to perceived parenting styles among 10-15-year-old (pre-) adolescents

\begin{tabular}{|c|c|c|c|c|}
\hline Variables & & $\mathrm{N}$ & M & H \\
\hline \multirow{4}{*}{ How many times a week do you have breakfast? } & Democratic & 68 & .706 & \multirow{4}{*}{$11.944^{* * *}$} \\
\hline & Liberal & 121 & 1.248 & \\
\hline & Authoritarian & 70 & 1.000 & \\
\hline & Indifferent & 346 & 1.197 & \\
\hline \multirow{4}{*}{ How many times a week do you consume raw vegetables? } & Democratic & 68 & 1.353 & \multirow{4}{*}{3.611} \\
\hline & Liberal & 120 & 1.650 & \\
\hline & Authoritarian & 70 & 1.643 & \\
\hline & Indifferent & 347 & 1.597 & \\
\hline \multirow{4}{*}{ How many times a week do you consume fruits? } & Democratic & 67 & .881 & \multirow{4}{*}{3.003} \\
\hline & Liberal & 120 & .875 & \\
\hline & Authoritarian & 70 & 1.100 & \\
\hline & Indifferent & 346 & 1.012 & \\
\hline \multirow{4}{*}{ How many times a week do you drink soft drinks? } & Democratic & 68 & 1.000 & \multirow{4}{*}{$8.615^{*}$} \\
\hline & Liberal & 120 & 1.483 & \\
\hline & Authoritarian & 70 & 1.229 & \\
\hline & Indifferent & 344 & 1.355 & \\
\hline \multirow{4}{*}{$\begin{array}{l}\text { How many times a week do you train or exercise for more than an hour } \\
\text { (outside school)? }\end{array}$} & Democratic & 68 & 1.118 & \multirow{4}{*}{1.865} \\
\hline & Liberal & 121 & 1.298 & \\
\hline & Authoritarian & 70 & 1.157 & \\
\hline & Indifferent & 346 & 1.234 & \\
\hline \multirow{4}{*}{ How many hours a day do you watch TV? } & Democratic & 67 & .582 & \multirow{4}{*}{$7.658^{*}$} \\
\hline & Liberal & 121 & .876 & \\
\hline & Authoritarian & 70 & .629 & \\
\hline & Indifferent & 345 & .771 & \\
\hline \multirow{4}{*}{ How many hours a day do you spend using a computer? } & Democratic & 68 & .632 & \multirow{4}{*}{2.375} \\
\hline & Liberal & 120 & .867 & \\
\hline & Authoritarian & 70 & .671 & \\
\hline & Indifferent & 346 & .772 & \\
\hline
\end{tabular}

Note: $\mathrm{N}=$ number, $\mathrm{M}=$ mean, $\mathrm{df}=$ degrees of freedom, $\mathrm{H}=$ Kruskal-Wallis test, $\mathrm{p}=$ level of statistical significance, ${ }^{*}=\mathrm{p}<.05,{ }^{* * *}=\mathrm{p}<.001$.

Graph 1: Differences in physical activity and food-related practices in relation to perceived parenting styles among 10-15-year-old (pre-) adolescents

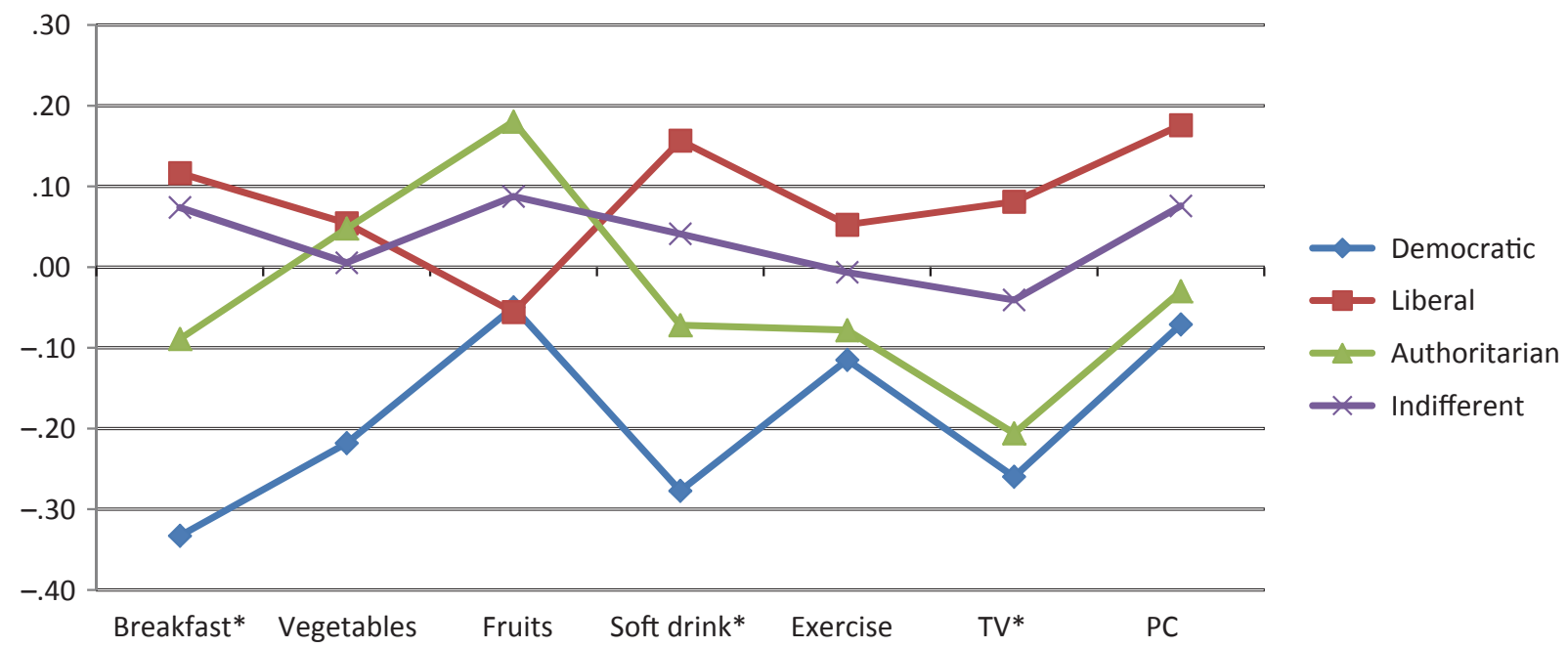




\section{Discussion}

In accordance with our assumption, we have confirmed the differences in the risk behaviour of pre-adolescents and adolescents aged from 10 to 15 years with respect to parents' parenting styles: democratic, liberal, authoritarian, and indifferent. In the overall risk behaviour, we focused on physical activity (or passivity) and the (pre-) adolescents' eating habits. Differences between the research groups were found, but not all were statistically significant. Nevertheless, the results support the previous theoretical and empirical backgrounds.

The parenting style is a general behavioural construct which sets the emotional context within which parents and children interact (Gustafson \& Rhodes, 2006). These have often been characterized as having at least two dimensions: demandingness (control) and responsiveness (warmth and acceptance in response to their children's needs). The balance between these two factors can be considered as a democratic parenting style, which has a positive impact on the risk behaviour of individuals. As the results show, individuals who have been raised with a democratic parenting style have been shown to be the least risky group in terms of their eating habits and physical activity. On the other hand, the authoritarian style is characterized by a high level of demandingness and a low level of responsiveness. These parents can control home activities such as exercise, TV watching, and PC usage; however, the level of risky food-related practices is high, which corresponds with the results of Savage, Fisher, and Birch (2007). Our results show that exercise, watching TV, and PC usage were low among individuals who had been raised with a democratic parenting style and an authoritarian parenting style. Democratic parents use reasoning to limit specific activities, while authoritarian parents use prohibition. The result in terms of the level of specific forms of risk behaviour is similar, but the parent-child relationship has a different quality.

Interestingly, the individuals who had been raised with liberal and indifferent parenting styles were shown to be the most risky group in terms of their eating habits and physical activities. The liberal parenting style is characterized by a low level of demandingness and high/moderate level of responsiveness. Logically, these children have the freedom to choose activities that are not controlled, which results in a high level of risk behaviour. Those individuals who had been raised with a liberal parenting style showed a moderate level of fruit consumption (compared to those individuals who had been raised with authoritarian and indifferent parenting styles); however, this variable is not statistically significant among the research groups. As the theoretical backgrounds predict (Čáp \& Boschek, 1994), the individuals who were raised with an indifferent parenting style are shown to be the group at highest risk in terms of their eating habits and physical activities. These individuals achieved moderate/high scores for all the observed variables, which may be caused by parents' disentanglement or different levels of demandingness and responsiveness. This can cause confusion and tendency for risk behaviour practices.

Although the study shows interesting results, singleitem analyses do not allow an in-depth and detailed examination of specific factors. Further research should also focus on the potential differences in watching TV vs. watching videos (such as those on YouTube) and using a PC vs. using a smartphone by (pre-) adolescents. Such changes in item wording might show a more pronounced correlation of risk behaviour and the different parenting styles. Also, further research might examine preferences for specific food types, fruits and vegetables, which would provide more detailed information on lifestyles in particular families differentiated according to parenting styles. These results are useful for practice, and allow psychologists and school psychologists to identify educational and behavioural problems on the basis of parenting styles, or vice versa, on the basis of the preadolescent lifestyle. This information might allow a psychologist to take specific measures, or develop prevention programmes for students and parents.

\section{Acknowledgement}

This paper is published within the frame of the project IGA_FF_2019_016: Psychologický výzkum ve vybraných oblastech pedagogické a klinické psychologie IV. No conflict of interests is assumed.

\section{Literature}

Abar, B., Carter, K. L., \& Winsler, A. (2009). The effects of maternal parenting style and religious commitment on self-regulation, academic achievement, and risk behavior among African-American parochial college students. Journal of Adolescence, 32(2), 259-273.

Abedini, Y., Zamani, B. E., Kheradmand, A., \& Rajabizadeh, G. (2012). Impacts of Mothers' Occupation Status and Parenting Styles on Levels of Self-Control, Addiction to Computer Games, and Educational Progress of Adolescents. Addiction and Health, 4(3/4), 102-110.

Arnett, J. J. 2000. Emerging adulthood: A theory of development from the late teens through the twenties. American Psychologist, 55(5), 469-480.

Barradas, D. T., Fulton, J. E., Blanck, H. M., \& Huhman, M. (2007). Parental influences on youth television viewing. The Journal of Pediatrics, 151, 369-373.

Brustad, R. (1993). Who will go out and play-parental and psychological influences on children's attraction to physical activity. Pediatric Exercise Science, 5(3), 210-223.

Čáp, J., \& Boschek, P. (1994). Dotazník pro zjištovaní spůsobu výchovy v rodine. Príručka. Bratislava: Psychodiagnostika. Čerešník, M. (2016). Hraničná zóna. Rizikové správanie $v$ dospievaní. Nitra: UKF. 
Čerešník, M., \& Čerešníková, M. (2019). Relation to own body and risk behavior expressions of adolescents in the system of lower secondary education. In: $P h D$ Existence 9: česko-slovenská psychologická konference (nejen) pro doktorandy a o doktorandech, 21.-22.01.2019, Olomouc. Palacký University Olomouc.

Chiarlitti, N. A., \& Kolen, A. M. (2017). Parental Influences and the Relationship to their Children's Physical Activity Levels. International Journal of Exercise Science, 10(1), 205-212.

Darling, N., \& Steinberg, L. (1993). Parenting style as context: An integrative model. Psychological Bulletin, 113(3), 487-496. Gray, C., \& Jennings, D. (1999). Adolescent risk behavior and influence on parental education. Journal of American Board of Family Medicine, 12(6), 435-447.

Gustafson, S. L., \& Rhodes, R. E. (2006). Parental correlates of physical activity in children and early adolescents. Sports Medicine, 36, 79-97.

Jago, R. (2011). Parenting styles, parenting practices, and physical activity in 10-to 11-year olds. Journal of Preventive Medicine, 52(1-3), 44-47.

Jessor, R. (1991). Risk behavior in adolescence: A psychosocial framework for understanding and action. Journal of Adolescent Health, 12(8), 597-605.

Kausar, R., \& Pinquart, M. (2016). Gender Differences in the Associations between Perceived Parenting Styles and Juvenile Delinquency in Pakistan. Pakistan Journal of Psychological Research, 31(2), 549-568.

Labáth, V., et al. (2001). Riziková mládež. Možnosti potenciálnych zmien. Praha: SLON.

Mayerová, K. (2013). Rodinná výchova a motivácia ako činitele úspešnosti adolescenta $\mathrm{v}$ kontexte celoživotného vzdelávania. In: E. Lukač (Ed.), Metamorfózy edukácie I. Katedra andragogiky. Prešov: FHPV PU, $144 \mathrm{p}$.

Newman, K., Harrison, L., Dashiff, C., \& Davies, S. (2008). Relationships between parenting styles and risk behaviors in adolescent health: an integrative literature review. Revista Latino-Americana de Enfermagem, 16(1), 142-150.

Prezza, M., Pilloni, S., Morabito, C., \& Sersante, C. (2001). The influence of psychosocial and environment factors on children's independent mobility and relationship to peer frequentation. Journal of Community and Applied Social Psychology, 11(6), 435-450.
Pugliese, J., \& Tinsley, B. (2007). Parental socialization of child and adolescent physical activity: a meta-analysis. Journal of Family Psychology, 21, 331-343.

Salmon, J., Timperio, A., Telford, A., Carver, A., \& Crawford, D. (2005). Association of family environment with children's television viewing and with low level of physical activity. Obesity Research, 13, 1939-1951.

Savage, J. S., Fisher, J. O., \& Birch, L. L. (2007). Parental Influence on Eating Behavior: Conception to Adolescence. $J$ The Journal of Law, Medicine \& Ethics, 35(1), 22-34.

Shloim, N. (2015). Parenting Styles, Feeding Styles, Feeding Practices, and Weight Status in 4-12-Year-Old Children: A Systematic Review of the Literature. Frontiers in Psychology, 6, 1-20.

Šnýdrová, I. (2008). Psychodiagnostika. Praha: Grada.

Strejček, J. (2009). Osobnost - pojem a podstata, utváření, formování. In: Metodický portal. Retrieved 8th March 2019 from https://goo.gl/46TD61

Tomšik, R., \& Čerešník, M. (2017). Adolescent»s Personality through Big Five Model: The Relation with Parenting Styles. AD ALTA, 2(7), 225-231.

Veldhui, L., van Grieken, A., Renders, C. M., HiraSing, R. A., \& Raat, H. (2012). Parenting Style, the Home Environment, and Screen Time of 5-Year-Old Children; The 'Be Active, Eat Right' Study. PLoS ONE, 9(2), e88486. doi:10.1371/journal. pone. 0088486

\section{Informace 0 autorech}

Robert TOMŠIK*

Research Institute for Child Psychology and Pathopsychology, Cyprichova 42, Postcode: 831 05, Bratislava, Slovakia, email: robert.tomsik@vudpap.sk

\section{Martin DOLEJŠ}

Department of Psychology, Faculty of Arts, Palacký University Olomouc, Kř́žzovského 10, Postcode: 771 80, Olomouc, Czech Republic, email: martin.dolejs@upol.cz 